\title{
OLAH DESAIN MODUL APUNG PADA HUNIAN APUNG TUMBUH DI MUARA ANGKE
}

\author{
Alexander Kevin Gunarso ${ }^{11}$, Priscilla Epifania Ariaji ${ }^{21}$ \\ 1)Program Studi S1 Arsitektur, Fakultas Teknik, Universitas Tarumanagara, kevingunarso@gmail.com \\ 2) Program Studi S1 Arsitektur, Fakultas Teknik, Universitas Tarumanagara, priscillae@ft.untar.ac.id
}

Masuk: 03-07-2021, revisi: 13-08-2021, diterima untuk diterbitkan: 23-10-2021

\begin{abstract}
Abstrak
Hunian Apung merupakan jenis hunian yang menjadi alternatif hunian pada daerah pesisir yang rawan banjir dan terdampak fenomena penurunan muka tanah. Perancangan hunian apung memiliki tujuan untuk memberikan hunian yang aman dan layak, beserta dengan fasilitas penunjang dan utilitas yang mandiri. Konsep hunian apung pada Kawasan Muara Angke, Jakarta Utara merupakan respon arsitektur terhadap fenomena penurunan muka tanah yang terus terjadi di pesisir Pantai Jakarta, hingga mencapai $18 \mathrm{~cm} /$ tahun. Dalam melakukan perancangan bangunan apung, struktur apung menjadi hal yang paling utama. Dibutuhkan konsep struktur apung yang efektif dan efisien serta memiliki ketahanan terhadap gelombang air laut. Selain itu, rancangan struktur apung juga memiliki kemudahan untuk perawatan dan reparasi, serta struktur yang mampu mengakomodasi beban hunian. Metode penelitian melalui pengumpulan data, analisis material, dan perhitungan kapasitas struktur, sehingga menghasilkan sebuah konsep struktur apung modular. Hasil dari penelitian ini berupa rancangan modul struktur apung berbentuk heksagonal yang terdiri dari 2 jenis material, yaitu drum plastik dan b-foam (Expanded Polystyrene). Rancangan struktur apung kemudian diterapkan pada bangunan sesuai fungsi, seperti hunian, pasar dan kebutuhan lain. Pemilihan material juga telah memenuhi standar perhitungan daya apung. Sehingga, rancangan modul struktur apung dapat digunakan untuk menunjang kegiatan masyarakat dengan aman dan ramah lingkungan.
\end{abstract}

Kata kunci: hunian apung; modul apung; muara angke; rumah tahan banjir; struktur apung tumbuh

\begin{abstract}
Floating Housing is a house type which is an altrnative housing model in coastal areas with prone to flood and affected by land subsidence phenomenon. The purpose of floating housing design is to give safe and proper housing, with the supporting facilities and independent utilities. Floating housing concept in Muara Angke, North Jakarta is an architectural response to the land subsidence, that keep happening in North Jakarta Coast up to $18 \mathrm{~cm} /$ year. In doing a floating housing design, floating structure is the most important thing. It needs effective and efficient floating structure concept and has resistance to sea waves. Besides that, floating structure must easy to maintenance, and repair, also accomodate the residential loads. Research method in this project is collecting data, material analysis and structure calculations, so as to produce a modular floating structure concept. The results of this research is hexagonal floating structure module made from 2 kind of material, that is plastic drum and b-foam (Expanded Polystyrene). Then, the floating structure design applied to the building according to its function, such as house, markets, and other needs. Material selection has follow the standard buoyancy calculation. So, the floating structure module design can use to support community activities safely and eco friendly.
\end{abstract}

Keywords: floating housing; floating modul; flood resistant house; growth floating structure; muara angke

\section{PENDAHULUAN}

Penurunan muka tanah merupakan permasalahan yang serius di berbagai wilayah Indonesia, terutama pada wilayah pesisir. Fenomena ini juga terjadi pada Kota Jakarta dengan salah satu wilayah paling parah adalah Muara Angke, Jakarta Utara dengan penurunan tanah rata - rata 18 
$\mathrm{cm} /$ tahun. Akibatnya, terjadi beberapa permasalahan seperti banjir rob, yang terjadi setiap tahun dan banyaknya bangunan yang terendam air dan berada di bawah permukaan air laut, serta kerusakan infrastruktur yang kemudian menyebabkan menurunnya kualitas kehidupan masyarakat di pesisir Muara Angke. Konsep Bangunan apung menjadi salah satu alternatif bentuk hunian yang dapat diterapkan. Namun, bangunan apung membutuhkan struktur apung yang memadai dan memenuhi standar yang ada.

\section{Latar Belakang}

Sistem hunian apung merupakan alternatif yang populer untuk menyelesaikan permasalahan di pesisir, seperti penurunan muka tanah, dan banjir rob. Dengan adanya sistem hunian apung beserta fasilitasnya, diharapkan kehidupan manusia pada hunian apung tidak mengganggu ekosistem sekitar, yang sudah tercemar dan mengalami kerusakan. Sehingga dengan relokasi menuju hunian apung, lingkungan alam di wilayah darat dan laut pesisir dapat dilakukan perbaikan, atau penghijauan kembali. Perancangan bangunan apung, membutuhkan teknologi sistem struktur yang dapat mengakomodasi seluruh kegiatan di atasnya. Selain itu, untuk fungsi hunian dibutuhkan struktur apung yang memiliki ketahanan dan harga yang terjangkau. Sehingga, mudah untuk dilakukan reparasi oleh masyarakat yang tinggal pada hunian apung.

\section{Rumusan Permasalahan}

a. Bagaimana sistem struktur apung yang cocok pada rancangan Hunian Apung Tumbuh di Muara Angke?

b. Material seperti apa yang cocok untuk struktur apung?

c. Struktur apung seperti apa yang dapat efektif dan efisien digunakan?

\section{Tujuan}

Tujuan dari penelitian ini, antara lain:

a. Menciptakan sebuah acuan struktur terapung yang dapat difungsikan sebagai fasilitas bagi masyarakat.

b. Menciptakan hunian apung yang aman, tahan terhadap bencana dan beradaptasi dengan kondisi lingkungan sekitar.

c. Menciptakan hunian apung yang dapat bertumbuh dan berkembang seiring bertambahnya kebutuhan.

\section{KAJIAN LITERATUR}

\section{Penurunan Muka Tanah}

Penurunan muka tanah atau land subsidence adalah fenomena turunnya permukaan tanah dibanding titik referensi. Fenomena ini sering terjadi di daerah pesisir yang difungsikan sebagai perkotaan, kawasan gambut, dan eksploitasi migas. Penurunan muka tanah menjadi salah satu masalah terbesar dan menjadi ancaman besar bagi Indonesia dan 34 negara lainnya, serta berdampak bagi $19 \%$ populasi manusia di dunia.

Penurunan muka tanah secara umum disebabkan oleh beberapa faktor, yaitu faktor alam, ekstrasi air tanah, dan beban massa bangunan. Faktor alam disebabkan oleh siklus geologi seperti gempa bumi, pergeseran tanah, dan fenomena sedimentasi tanah. Faktor ekstrasi air tanah disebabkan oleh pemanfaatan air tanah untuk menunjang kehidupan manusia, sehingga volume tanah pada lapisan tertentu berkurang. Faktor beban massa bangunan menyebabkan pemampatan pada lapisan tanah. Akibat dari penurunan muka tanah dapat mengancam keselamatan lingkungan dan manusia. Dampak yang terjadi, antara lain banjir rob, intrusi air laut, dan kerusakan infrastruktur. 


\section{Hunian Apung}

Hunian apung merupakan bentuk alternatif hunian yang berdiri di atas air dengan struktur yang mengapung. Bjarke Ingels Group (BIG) pada proyek hunian apung Oceanix City, memaparkan beberapa kriteria untuk dipenuhi dalam mencapai hunian apung yang ramah lingkungan, antara lain : Konstruksi Modular (Modular Construction), Zero Energy, Zero Waste System, Fresh Water Autonomy, Plant Based Food, Shared Mobility, Habitat Regeneration.

Hunian apung harus menggunakan energi dan sumber air yang terbarukan, seperti dari air laut dan air hujan, listrik tenaga angin atau surya dan pemanfaatan limbah untuk dijadikan sumber energi. Sehingga, kehadiran sebuah hunian apung tidak menciptakan ekosistem baru yang merusak lingkungan alam.

\section{Struktur Apung}

Struktur apung merupakan alternatif dari tanah dalam sebuah bangunan apung. Secara umum, struktur apung yang populer ada 2 tipe, yaitu struktur apung semisubmersible, dan ponton. Struktur Semisubmersible merupakan struktur dengan menggunakan tabung dan struktur ballast. Struktur ponton merupakan struktur terapung yang cocok untuk wilayah perairan tenang dengan sistem seabed. Terdapat beberapa kelebihan dari struktur apung, antara lain konstruksi yang lebih hemat biaya, tidak mengganggu ekosistem sekitar, pengerjaan yang lebih cepat, dan tahan gempa karena konstruksi tidak tertanam di dalam tanah.

\section{Material B-Foam}

Material B-Foam merupakan salah satu material apung sederhana yang populer digunakan di Indonesia. Jenis material ini memiliki berat jenis kurang dari $3 \%$ berat jenis air, sehingga memiliki kemampuan sangat baik untuk mengapung. B-Foam berasal dari material Exapanded Plystyrene (EPS) yang cocok untuk digunakan sebagai material struktur apung, dan konstruksi bangunan di atas struktur apung. Material ini memiliki beberapa keunggulan diantara lain, tahan lama dan tidak mudah keropos, tidak dapat mengalami kebocoran, dan ramah lingkungan karena tidak mengandung CFC. B-Foam juga merupakan material yang diproduksi lokal di Indonesia, sehingga mudah untuk perawatan dan reparasi. Penggunaan material ini pada umumnya untuk dermaga apung, jembatan apung, dan kawasan wisata apung.

\section{Pengolahan Air pada Hunian Apung}

Hunian apung memiliki beberapa kriteria yang salah satunya adalah Fresh Water Autonomy, dimana hunian apung harus memiliki sistem pengolahan air bersih dan air kotor yang mandiri. Terdapat beberapa sistem pengolahan air mandiri pada hunian apung, antara lain :

a. Desalinasi Air Laut

Desalinasi air laut adalah teknik pengubahan air laut menjadi air tawar. Air laut di pompa menuju mesin desalinasi dan diolah menjadi air tawar. Sehingga air hasil olahan desalinasi, dapat digunakan untuk menunjang kehidupan pada hunian apung.

b. Panen Air Hujan

Panen air hujan ,atau rainwater harvesting adalah sistem penampungan air hujan yang dapat digunakan untuk memenuhi kebutuhan rumah tangga, menyiram tanaman, dan fungsi pemanasan. Proses ini cocok untuk daerah dengan curah hujan tinggi.

c. Greywater and Wastewater Treatment

Sistem Greywater and Wastewater Treatment adalah proses penyaringan air bekas dan air kotor agar tidak ada limbah yang dibuang secara langsung ke perairan. Air dari hasil pengolahan ini dapat digunakan untuk penyiraman tanaman. 


\section{Pengolahan Limbah pada Hunian Apung}

Dalam merancang hunian apung, terdapat kriteria Zero Waste yang harus dipenuhi. Limbah yang dihasilkan tidak dapat dibuang secara langsung ke perairan, karena akan mencemari lingkungan. Terdapat beberapa sistem pengolahan limbah yang dapat diterapkan pada hunian apung, antara lain :

\section{a. Anaerob Digester}

Anaerob Digester adalah sistem pengolahan limbah organik yang diubah menjadi biogas dengan mesin digester. Biogas yang dihasilkan dapat memenuhi kebutuhan gas masyarakat dan kebutuhan pemanas, serta menghasilkan listrik yang dapat menunjang kebutuhan.

b. Pengomposan

Teknik pengomposan dapat menghasilkan pupuk yang dapat digunakan untuk kebutuhan bercocok tanam.

c. Daur Ulang

Sampah anorganik yang dihasilkan dapat dilakukan pemilahan, dan produksi daur ulang. Sehingga tidak dibuang ke perairan.

\section{METODE}

Penelitian ini diawali dengan perancangan tugas akhir Studio Perancangan Arsitektur, yaitu Bəntala Məəapun, Hunian Apung Tumbuh dengan tapak terletak Kawasan Muara Angke, Jakarta Utara. Pemilihan kawasan pada Muara Angke, dilatar belakangi oleh kondisi masyarakat setempat yang terdampak bencana banjir rob akibat penurunan muka tanah paling parah di Jakarta. Penurunan muka tanah yang terjadi sudah sangat parah dan cepat, mencapai $18 \mathrm{~cm} /$ tahun dengan ketinggian banjir mencapai $60 \mathrm{~cm}$. Sehingga, jika penurunan muka tanah terus terjadi maka kawasan ini dipresiksi akan tenggelam lebih cepat. Dalam proyek hunian apung ini, hal yang paling utama adalah struktur apung.

\section{DISKUSI DAN HASIL}

Isu

Latar belakang dari penelitian ini adalah penurunan muka tanah yang terjadi di Jakarta Utara dan dampak yang terjadi terhadap masyarakat luas. Pemilihan isu bedasarkan tema "Melampaui Ekologi" atau "Beyond Ecology" yang menjadi acuan dalam penelitian.

\section{Tapak}

Tapak perancangan berlokasi di Jalan Dermaga Ujung 1, Pluit, Kecamatan Penjaringan, Kota Jakarta Utara, DKI Jakarta. Tapak berada di kawasan Muara Angke yang merupakan kawasan pelabuhan kapal ikan di Jakarta Utara, dengan fasilitas penunjang seperti tempat pelelangan dan pasar ikan.

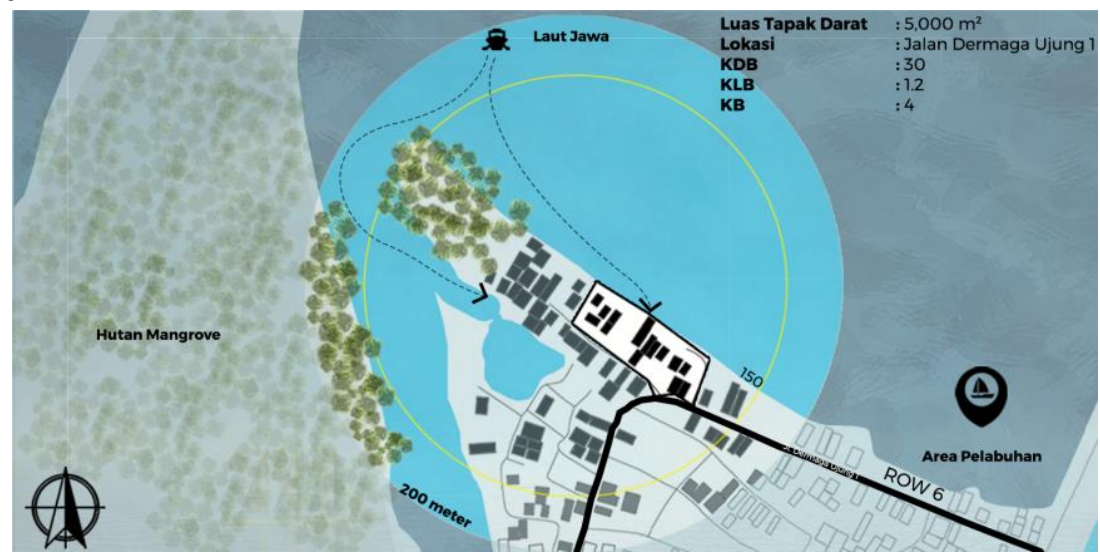

Gambar 1. Tapak Perancangan

Sumber: Penulis, 2021 
Kondisi eksisting tapak merupakan hunian nelayan dan dermaga kapal ikan, serta area pengolahan berbahan baku hasil laut. Tapak dibagi menjadi 2, yaitu tapak darat dan laut. Tapak darat memiliki luas 5,000 m2 dengan KDB 30\%, KLB 1.2, dan KB 4. Tapak di lautan dengan radius 150 meter yang masih dalam jarak nyaman manusia berjalan.

\section{Konsep Material Struktur Apung}

Dalam perancangan struktur apung, terdapat beberapa kriteria pemilihan material struktur apung yang digunakan, antara lain :

1. Material yang dapat mengakomodasi seluruh kegiatan dalam proyek

2. Material yang tahan terhadap air dan banjir

3. Kemudahan untuk perawatan dan reparasi

4. Kapasitas material dalam menampung beban

5. Harga yang terjangkau untuk digunakan pada kawasan pemukiman pesisir.

Pada proyek Bəntala Məђapun terdapat 2 jenis material yang digunakan, antara lain :

a. Drum Plastik HDPE 200 Liter

Drum Plastik HDPE merupakan material yang mudah untuk didapatkan dan mudah untuk direparasi, serta memiliki harga yang terjangkau jika dibandingkan dengan ponton apung. Sehingga material ini cocok untuk digunakan pada hunian pesisir.

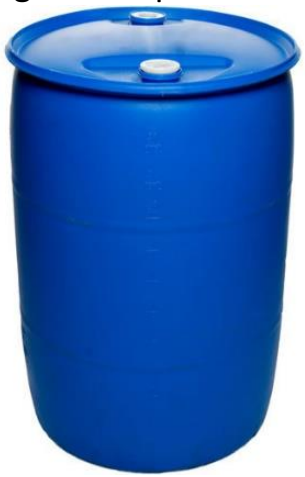

Gambar 2. Drum Plastik HDPE 200 Liter

Sumber: PT. Karya Sarana Drumindo, 2021

b. B-Foam / Expanded Polystyrene

Material B-Foam merupakan material Expanded Polystyrene (EPS) yang memiliki daya apung sangat baik dengan berati jenis kurang dari $3 \%$ dari berati jenis air. Sehingga material ini cocok untuk diaplikasikan sebagai struktur apung. Material ini juga diproduksi di Indonesia, sehingga mudah untuk mendapatkan dan reparasi.

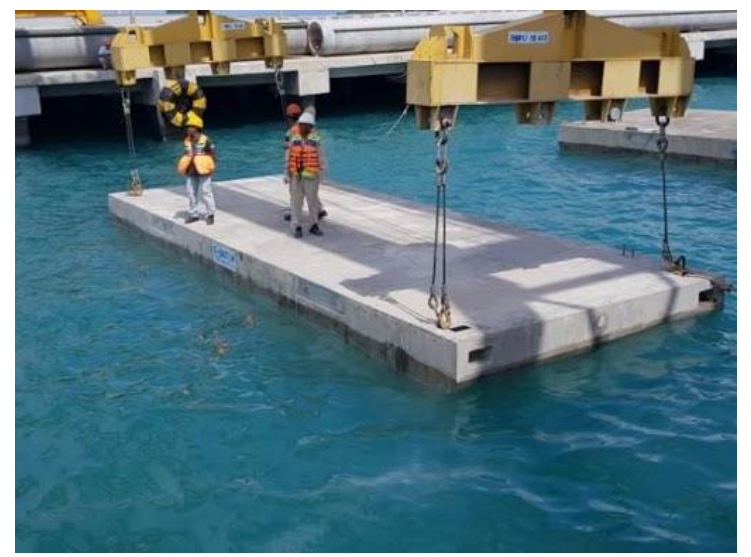

Gambar 3. Struktur Apung B - Foam

Sumber : www.bfoam.com, 2020 


\section{Spesifikasi Struktur Apung}

Terdapat 2 jenis olah desain struktur apung, yaitu struktur apung dengan drum plastik HDPE dan struktur apung dengan material B-Foam, dengan spesifikasi yang dapat menampung fungsi hunian pada proyek hunian apung Bəntala Məyapun dengan daya apung dan kapasitas.

Berikut spesifikasi struktur apung yang digunakan :

a. Struktur Drum HDPE 200 Liter

Struktur drum HDPE 200 liter disusun dan digabungkan dengan menggunakan pengikat yang terbuat dari material baja. Kemudian dipasang lantai dengan material B-Foam pada bagian atasnya.

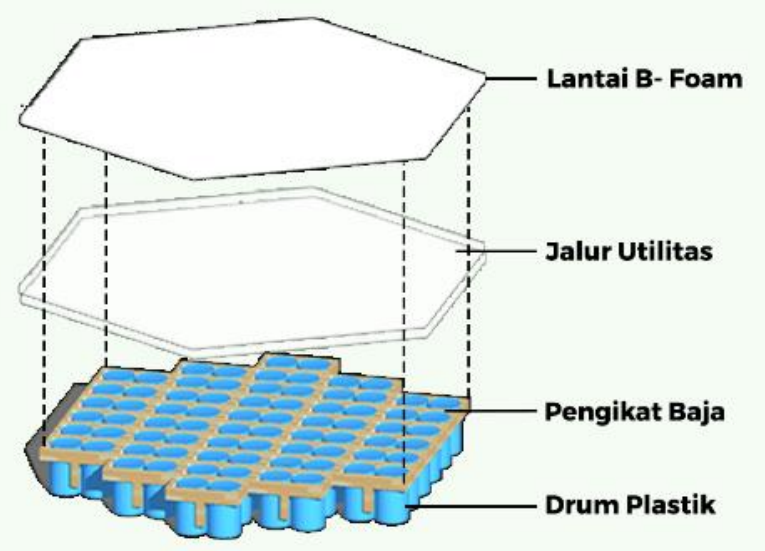

Gambar 4. Struktur Apung Drum HDPE 200 Liter Sumber : Penulis, 2021

Spesifikasi :

- Material Lantai : B-Foam / EPS

- Luas Lantai $\quad: 50 \mathrm{~m}^{2}$

- Tebal Lantai $\quad: 10 \mathrm{~cm}$

- Material Apung : Drum Plastik HDPE

- Ukuran Drum : 200 Liter

- Kebutuhan Drum : 76 Drum / modul

- Daya Apung : $: 246 \mathrm{~kg} / \mathrm{drum}(18,696 \mathrm{~kg} /$ modul $)$

b. Struktur Apung B-Foam / EPS

Modul struktur apung B - Foam diproduksi dan dirakit bagian lantai dan struktur apung, kemudian dirakit pada proyek.

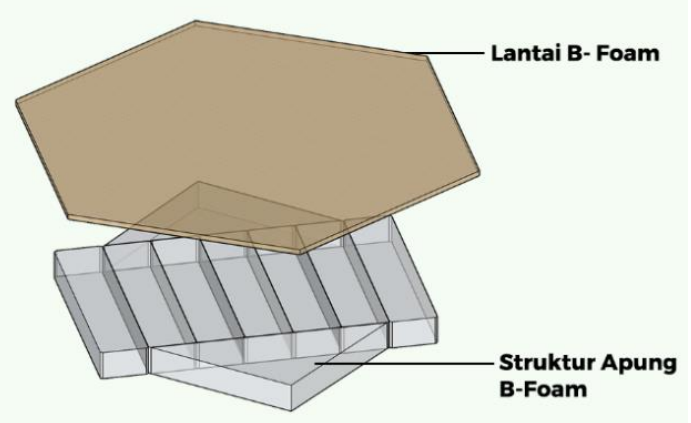

Gambar 5. Struktur Apung B-Foam Sumber: Penulis, 2021 


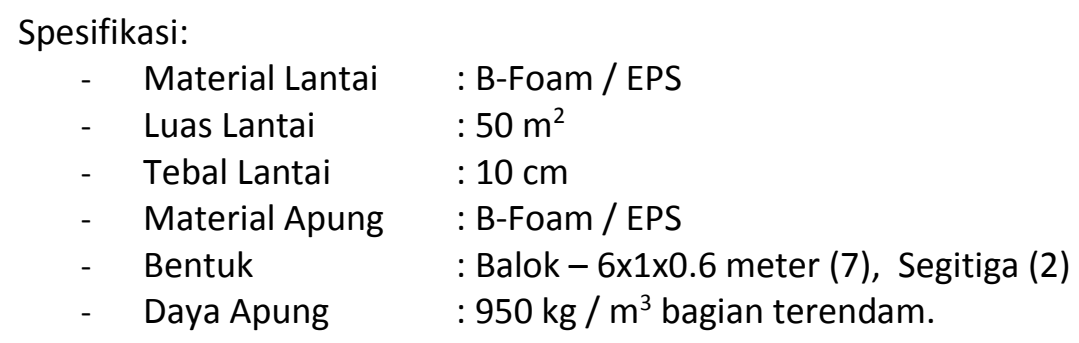

\section{Sambungan Antar Modul Struktur Apung}

Pada modul dasar apung, dibutuhkan sambungan yang berfungsi sebagai pengait antar modul agar tetap pada posisinya dan tidak hanyut terbawa air. Pengait antar modul juga harus rapih atau tersembunyi untuk menghindari kejadian yang tidak diinginkan bagi pejalan kaki, seperti tersandung.

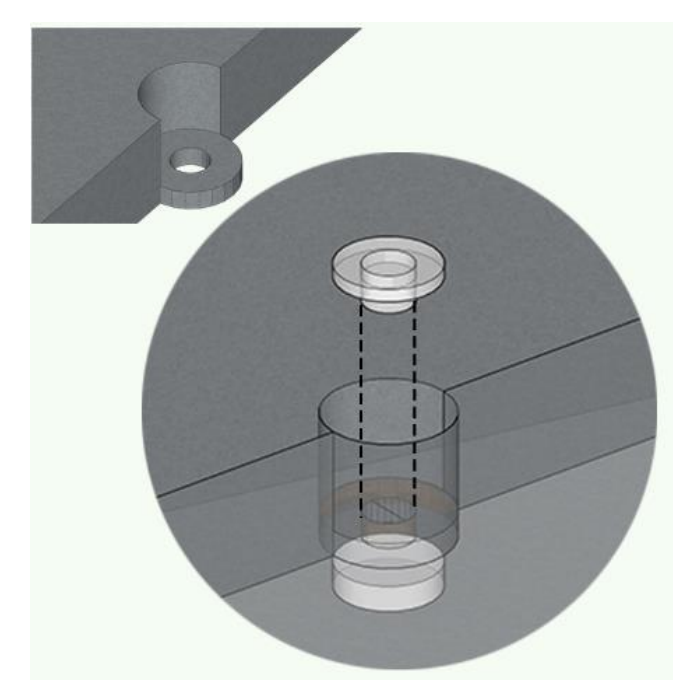

Gambar 6. Sambungan Modul Struktur Apung Sumber : Penulis, 2021

Sambungan antar modul yang digunakan pada proyek ini berbentuk lingkaran dengan pengait baut yang tersembunyi dan berjumlah 3 buah sambungan per sisi modul heksagonal. Berikut adalah gambar detail dari sambungan modul pada proyek Bəntala Məђapun.

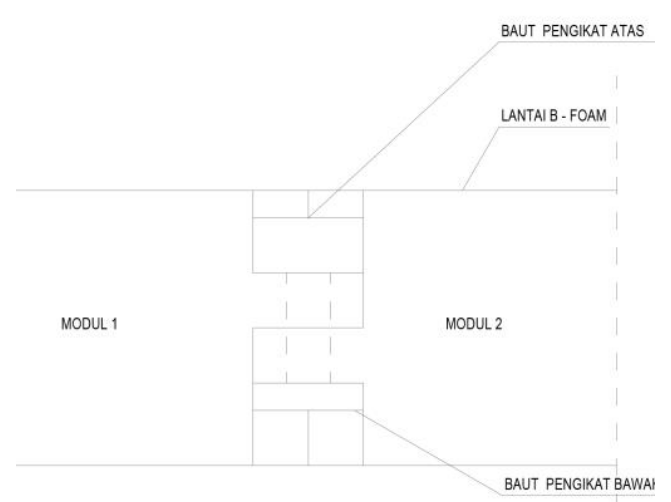

Gambar 7 . Detail Sambungan Modul Struktur Apung

Sumber : Penulis, 2021

\section{Katalog Modul Struktur Apung}

Dalam rancangan proyek Bəntala Mənapun, struktur apung Drum Plastik HDPE, dan B-Foam diaplikasikan menjadi modul - modul bangunan sesuai dengan fungsi yang dibutuhkan. 
Berikut adalah tabel katalog modul struktur apung pada proyek Bəntala Məワapun :

1. Modul Dasar

Tabel 1. Katalog Modul Dasar

\begin{tabular}{|c|c|c|}
\hline No & Tipe Modul & Deskripsi \\
\hline 1 & A1 & $\begin{array}{l}\text { Modul dasar dengan material apung } \\
\text { drum plastik HDPE yang berdiri } \\
\text { vertikal dan dapat digunakan untuk } \\
\text { dasar hunian. }\end{array}$ \\
\hline 2 & $\mathrm{~A} 2$ & $\begin{array}{l}\text { Modul dasar dengan material apung } \\
\text { B-Foam Floating Structure yang } \\
\text { dapat digunakan untuk area umum. }\end{array}$ \\
\hline 3 & A3 & $\begin{array}{l}\text { Modul dasar dengan material apung } \\
\text { drum plastik HDPE } 200 \text { Liter dengan } \\
\text { void pada bagian tengah yang dapat } \\
\text { digunakan sebagai keramba jaring } \\
\text { dan untuk modul sirkulasi. }\end{array}$ \\
\hline
\end{tabular}

Sumber: Penulis, 2021

2. Modul Fungsi

Tabel 2. Katalog Modul Fungsi

\begin{tabular}{ll}
\hline No & \multicolumn{1}{c}{ Deskripsi } \\
\hline 1 & $\begin{array}{l}\text { Modul hunian dengan luas } 36 \mathrm{~m}^{2} \\
\text { dengan kapasitas } 4 \text { orang. Modul } \\
\text { dasar terapung dan dapat } \\
\text { dikembangkan menjadi modul } \\
\text { komplek. }\end{array}$ \\
\hline 2 & $\begin{array}{l}\text { Modul rumah tipe deret dengan } \\
\text { kapasitas 4 KK / modul dan terletak } \\
\text { di daratan (pada tahap prototipe) } \\
\text { sebagari modul amfibi yang dapat } \\
\text { mengapung jika banjir. }\end{array}$
\end{tabular}

Sumber: Penulis, 2021 
3. Modul Utilitas

Tabel 3. Katalog Modul Utilitas

\begin{tabular}{cl}
\hline No & \begin{tabular}{l} 
Deskripsi \\
\hline 1
\end{tabular} \\
\hline 2 & $\begin{array}{l}\text { Modul utilitas pengolahan } \\
\text { limbah kawasan dengan } \\
\text { kapasitas } 9 \text { ton sampah / } \\
\text { modul. }\end{array}$ \\
Pengolahan Air & $\begin{array}{l}\text { Modul utilitas pengolahan air } \\
\text { yang terdiri dari desalinasi air } \\
\text { laut, water treatment, dan } \\
\text { rainwater harvesting dengan } \\
\text { kapasitas 400,000 Liter / } \\
\text { modul. }\end{array}$
\end{tabular}

Sumber : Penulis, 2021

\section{Aplikasi Modul Struktur Apung}

Modul bangunan prefabrikasi yang terdiri dari dinding, lantai, atap dan perabotan kemudian diaplikasikan pada modul dasar yang tersedia. Sehingga bangunan dapat digunakan sesuai dengan program yang ada.

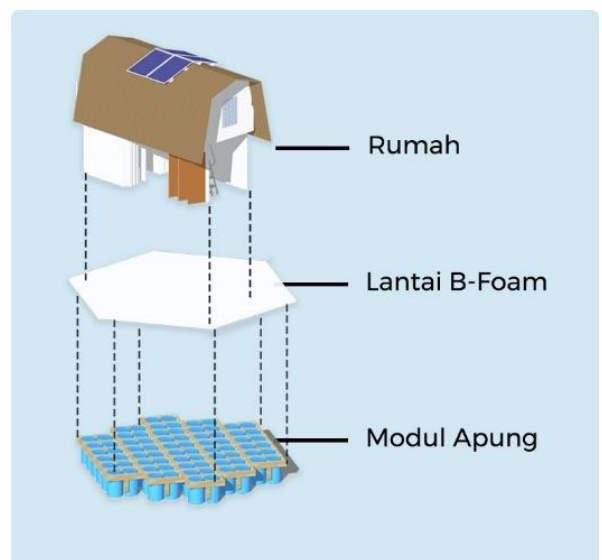

Gambar 8. Aplikasi Modul Struktur Apung pada Bangunan Sumber : Penulis, 2021

Gambar di atas merupakan contoh pengaplikasian modul dasar, modul apung, dan modul bangunan pada modul R1 (Rumah 1).

Perhitungan Modul Apung pada Proyek Bəntala Mə๖apun

Berikut merupakan contoh perhitungan aplikasi modul struktur apung pada salah satu modul kompleks hunian pada proyek Bəntala Mə⿹apun, yaitu modul Rumah 1 (R1). Dalam membentuk modul yang kompleks dibutuhkan perhitungan penggunaan masing - masing modul. Berikut contoh perhitungan modul pada kompleks hunian R1 : 


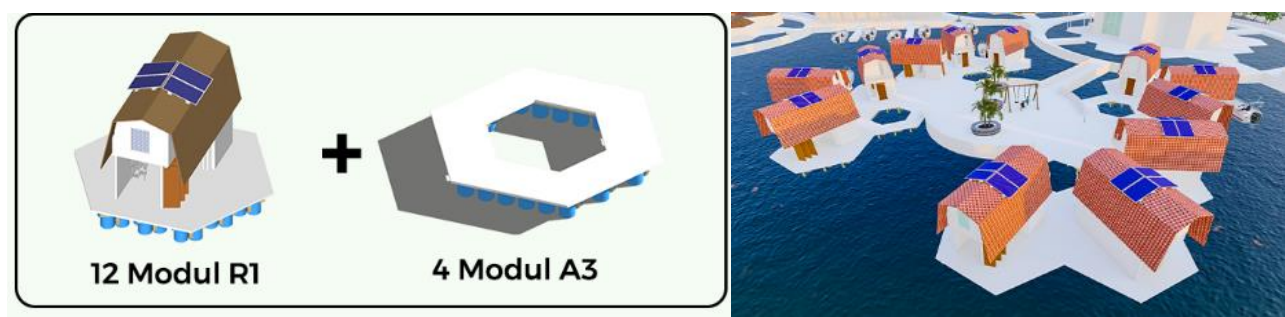

Gambar 9. Aplikasi Modul Rumah 1 (R1)

Sumber : Penulis, 2021

Untuk membentuk 1 modul kompleks R1 dengan kapasitas $12 \mathrm{KK}$, dibutuhkan 12 unit modul R1 dan 4 unit modul A3 yang kemudian digabungkan dengan modul sirkulasi utama. Sistem modul pada proyek apung mempermudah dalam produksi komponen - komponen yang dibutuhkan dan kemudahan dalam reparasi karena modul apung ini dapat dilepas pasang.

\section{KESIMPULAN DAN SARAN}

\section{Kesimpulan}

Penurunan muka tanah merupakan fenomena yang terjadi dan berdampak buruk bagi masyarakat luas, seperti banjir rob dan tenggelamnya kawasan oleh air. Dalam menghadapi fenomena ini, masyarakat sudah seharusnya memiliki cara hidup yang baru, yang salah satunya adalah mengapung di atas air, seperti pada proyek Bəntala Mənapun. Dengan cara hidup mengapung, struktur apung yang memadai merupakan hal yang paling utama. Dalam merancang struktur apung, perancang harus memperhatikan beberapa kriteria yaitu : Faktor keselamatan, Daya apung material yang digunakan, Kapasitas angkut struktur apung, Kemudahan dalam mendapatkan material, Kemudahan perawatan dan reparasi, Sistem MEP, Harga struktur apung yang terjangkau. Dengan memperhatikan beberapa kriteria tersebut, maka rancangan struktur apung layak, efektif, dan efisien untuk digunakan sebagai hunian dan fasilitas.

\section{Saran}

Bagi pembaca atau perancang proyek apung, disarankan untuk memperhatikan beberapa kriteria di atas untuk mencapai proyek apung yang aman dan efektif digunakan.

\section{REFERENSI}

Frick,H. (2006). Arsitektur Ekologis : Konsep Arsitektur Ekologis di Iklimtropis, Penghijauan Kota dan Kota Ekologis, serta Energi Terbarukan. Yogyakarta: Kanisius.

Haryanti, R. (2019). PBB Ungkap Desain Pembangunan Kota Terapung "Oceanix City". diunduh 2 Maret 2021. https://properti.kompas.com/read/2019/04/04/190000421/pbb-ungkapdesainPembangunan-kota-terapung-oceanix-city

Hidayat, R. (2018). 2050, Jakarta Utara 'tenggelam': Semua yang perlu Anda Ketahui. diunduh 8 Februari 2021. https://www.bbc.com/indonesia/resources/

Ingels, B. (2019). Oceanix City. diunduh 1 Maret 2021. https://big.dk/\#projects-sfc.

Neufert, E. (1996). Data Arsitek Jilid 1. Jakarta : Erlangga.

Neufert, E. (2002). Data Arsitek Jilid 2. Jakarta : Erlangga.

Panero, J dan Zelnik, M. (1979). Human Dimension \& Interior Space. New York : Whitney Library of Design.

Sutanto, A. (2020). Peta Metode Desain. Jakarta.

Watanabe, E. (2004). Very Large Floating structures : Application, Analysis and Design. SingapurA: NUS.

Zitzman, L. (2019). Floating Cities: Your Guide to the Future of Urban Construction. diunduh 1 Maret 2021. https://www.bigrentz.com/blog/floating-cities.

www.b-foam.com. (2019, 17 Oktober). B-foam Floating Structures. Diakses pada 2 Maret 2021. http://www.b-foam.com/floating/ 